\title{
Exploring the History of the First Social Enterprise Type: Social Co-Operation in the Italian Welfare System and its Replication in Europe, 1970s to 2011
}

\section{ABSTRACT}

"Social enterprise" is an umbrella term that covers a broad range of organisations, which differ to a greater or lesser extent in their visibility, scope and dissemination, in the various countries, but which share the explicit pursuit of social objectives, in the world of business and in an on-going manner, by directly producing goods and services that benefit disadvantaged persons and the community at large. The aim of this paper is to investigate one of the first, if not the very first, social enterprise in Europe, the Italian social co-operative. It begins with a survey of the economic and social environment of the 1970s giving rise to this form of co-operative. The paper then outlines its original features and the legislation adopted to regulate it: social co-operatives, in fact, were not part of the tradition of the co-operative movement and, therefore, were not recognised by the Italian law. This is followed by a statistical analysis, beginning with the first survey carried out to monitor this phenomenon and ending with the more recent statistical data. Finally, an overview is provided of the social enterprises launched in the major European countries and based on the Italian "prototype".

\section{KEY-WORDS}

WELFARE STATE, WELFARE SYSTEM, BUSINESS HISTORY, SOCIAL ENTERPRISE, CO-OPERATIVE, SOCIAL CO-OPERATIVE, MUTUAL AID, CHARITY

\section{Acknowledgments}

The author would like to thank Carlo Borzaga, Andrea Leonardi and the two anonymous reviewers for their helpful suggestions, and Giulia Tallarini for editorial assistance. 


\section{Introduction}

The aim of this paper is to investigate-according to a historical approach-how co-operative enterprises in Italy have helped renew the welfare system, by introducing an entirely new cooperative model based on "social co-operation". This model is one of the first, if not the very first, social enterprise in Europe. This case is of special interest, firstly because social co-operatives differ from more traditional co-operatives, and secondly because this type of enterprise was invented and adopted for the first time in Italy, spreading later to other European countries. In other words, the social co-operative model may be considered a typically Italian "brand", similar to the creation, at the end of the 19th century, of the farm labourer co-operatives, another purely Italian invention (Zamagni and Zamagni, 2010). Regarding other historical sectors, Italy too, like the other countries, adopted types of enterprises created elsewhere and which can be classed in four distinct groups: British consumer co-operatives, French production and work cooperatives, German credit co-operatives and Scandinavian farmer co-operatives. While there is a large body of literature on all these types of co-operatives and also on individual national cases (Battilani and Schröter, 2012; Hoynt and Menzani, 2012; Zamagni, 2012), this paper is the first business history article dedicated to the Italian social co-operative movement presented within an international framework.

It begins with a brief review of the first initiatives set up to fight against poverty over the centuries. Then, the article investigates the economic and social environment of the 1970s giving rise to this form of co-operative. The paper outlines its original features and the legislation adopted to regulate it: social co-operatives, in fact, were not part of the tradition of the co-operative movement and, therefore, were not recognised by Italian law. This is followed by a statistical analysis, beginning with the first survey carried out to monitor this phenomenon and ending with the more recent statistical data. Finally, an overview is provided of the social enterprises launched in the major European countries and based on the Italian "prototype". This paper is based on the available literature and on original research work carried out to reconstruct the history of social enterprises (Borzaga and Ianes, 2006; Ianes, 2009; Ianes and Tortia, 2010).

\section{Charity, self-help and public action: historical interventions in the social sphere}

Over the centuries, the problem of poverty has been tackled by different players in many different ways. The basic aim was to alleviate the suffering of people affected by economic hardship, by relieving the conditions of their economic and social fragility. It has been observed (Zamagni, 1997; 2000), in fact, that in all European countries it has been the different combination of charity, self-help and public action to intervene in the social sphere, producing goods and services of collective interest, exercising redistribution and advocacy as well, in favour of the more marginal members of society. 
Until the mid-19th century, in particular, the leading role was played by charitable institutions, permanent foundations called "Opere pie" in Italy (Woolf, 2000) ${ }^{1}$. Established by private initiative, on the basis of legacies and endowments, after forming the backbone of poor relief in the ancien régime (Jütte, 1984; Woolf, 1986) they have further consolidated their role by organising handouts to paupers and social and health programs for the poor, orphans and other weaker social groups. Other initiatives were put into place by financial institutions, such as savings banks and so-called "Monti di pietà" (pawnshops) (Carbonell, 2012), or by self-help organisations, such as mutual aid or friendly societies (Gosden, 1961), which insured their members against the risks of sickness, accidents, invalidity and loss of life (O'Brien and Fenn, 2012). Co-operative companies, in fact, originated from the latter organisations, for the purpose of defending the purchasing power of labourers, finding jobs, lending money to farmers and setting up agro-industrial operations for fostering their emancipation (Leonardi, 2000; MacPherson, 2008).

Over time, the role of the charitable institutions and mutual aid societies gradually were downscaled within the framework of social policies. The former, in fact, tended to impair individual responsibility, while self-help organisations, although they required the active participation of their members-who were also the recipients of the services_-proved unable to guarantee an insurance cover to the jobless as well, i.e. to those who could not afford to pay the periodical membership fee (Zamagni, 1997).

This led to the emergence of government-sponsored programs. The first experimental social legislation, which provided for the direct intervention of the State in the field of health care and social insurance, was launched in Germany by Otto von Bismarck, who between 1883 and 1889 introduced a welfare system founded on state funded and managed social insurance programs. From then on, in practically all the European countries, the public-sector presence in the field of social welfare significantly intensified (Mommsen, 1981; Hennock, 1987; 2007; Quine, 2002). A further step forward occurred in 1942 when, even at the peak of the war, the British Government approved the Beveridge Plan, which was to become the cornerstone of the welfare state reform in the United Kingdom and which, after the war, inspired the vast majority of European countries in the establishment of their own welfare states (Bentley, 1966; Fraser, 1984; Douglas, 1986; Wilson and Wilson, 1993; Harris, 1997). It was in this period that there was a shift from a "social insurance" approach to the recognition of the "social security" rights to which citizens were entitled, alongside their civil and political rights (Klausen, 1998). In Europe, in fact, spread the idea that one of the duties of governments was to guarantee the social security of all citizens, supporting them from the "cradle to the grave". Social protection, therefore, should be extended to include the jobless and their families, moving beyond the traditional link between insurance and employment. Moreover, the welfare state should also cover the risks associated with loss of income, in order to effectively contrast the full range of adversities affecting people throughout their life. These were the guidelines that inspired the social security programs in European countries after World War

Of particular interest is the case of Bologna (Sneider, 2000). For France see: Jones (1982). For Great Britain see: Owen (1965) and Lewis (1995). 
II, albeit with differences from country to country, and eventually produced the various welfare systems: a mix between particularistic and universalistic inclusion. In particular, two main welfare models emerged: the German model, which continued to be based on workers' social insurance, and the Scandinavian model, which covered all citizens and all life's vicissitudes (Sven, 2014). Germany, France and Belgium adopted the former, the Scandinavian countries the latter, while other European countries—like Italy and the United Kingdom—-preferred a mixed approach (Zamagni, 1997).

As a result, the welfare operations of charitable institutions and mutual aid societies dwindled and all but disappeared, as reflected in the words of Borzaga and Santuari (2001: 168) "In Italy, therefore, the action of charities and voluntary organisations was progressively replaced by the direct intervention of public authorities [...]. This attitude towards non-profit organisations was strengthened between the First and the Second World Wars by fascism and, subsequently, by the building of the public welfare system"2. In actual fact, however, in countries like Italy, the principles set out in the Beveridge Report-and enshrined in the Italian Constitution of 1948 (Conte, Rossi and Vecchi, 2011)—struggled to make the transition from constitution to implementation. Therefore, in the 1970s, a new interest emerged in non-profit private enterprises with social objectives, providing services to individuals and the community. Faced with a deeply transformed society, both economically and socially, and a welfare state finding it harder and harder to fulfil its commitments, the public sector inevitably found itself shrinking and giving more and more space to other organisations, whose roots could be traced back to the co-operative and volunteer tradition of many European countries and which had come to be called "non-profit" or "third sector"3. Age-old solutions were thus rediscovered and renewed, adapted to the new needs, while original organisations were experimented, such as "social enterprises", which, together with the third sector as a whole, became a leading player in European welfare policies. "As to the concept of 'social enterprise',—say Defourny and Nyssens (2008a: 5) - it first appeared in Europe (a few years before it emerged in the United States), and more precisely in Italy, where it was promoted by a journal launched in 1990 and titled Impresa Sociale. The concept was introduced at the time to designate the pioneering initiatives for which the Italian Parliament created the legal form of "social co-operative" one year later. As will be shown, various other European countries have since passed new laws to promote social enterprises".

Therefore, "social enterprise" is an umbrella term that covers a broad range of organisations, which differ to a greater or lesser extent in their visibility, scope and dissemination, in the various

\footnotetext{
2 "The scaling down of the Italian non-profit sector began at the end of the nineteenth century. The first stage in the process was revision of the legislation on the Opere Pie, which the government and Parliament undertook primarily because the reform law of 1862 had not been uniformly applied or respected in the country's various regions" (Borzaga, 2004: 49-50).

3 Internationally, a literature appeared that analysed the non-profit sector from an economic perspective, although initially primarily in the United States: Weisbrod (1975; 1977); Hansmann (1980); Young (1980); Salamon and Anheier (1994).
} 
countries (Galera, 2014) ${ }^{4}$, but which share the explicit pursuit of social objectives, in the world of business and in an on-going manner, by directly producing goods and services that benefit disadvantaged persons and the community at large.

\section{The crisis of the welfare state, the rise of the service industry and unemployment}

The economic situation in the 1970s was heavily affected by the "energy crisis", which peaked a first time in 1973, with the so-called "first oil shock", followed in 1979 by the "second oil shock"s. Rising inflation and economic stagnation combined to form a mix referred to in economic literature as "stagflation" (Cornwall, 1984) triggering an economic cycle that generated massive unemployment.

The energy crisis significantly transformed the way people produced goods, lived and worked, which can be exemplified by the shift from the "triumphant" Fordist economic and industrial model - typical of the Italian boom between the 1950s and the 1960s, when the GDP increased by up to $6.7 \%$ per year (Brunetti, Felice and Vecchi, 2011) - to the loss of centrality of manufacturing and the growth of the services sector, providing services to businesses and individuals. The process proved seamless, there was no revolution of the sector of services. In the literature, the expression "neo-industrial" society is used, with reference to services to businesses, or "post-industrial" society, with regard to services to individuals (Fisher, 1935; Clark, 1951; Martinelli and Gadrey, 2000). Other factors have contributed to changing the living and working conditions of people, such as the competition from low-wage countries and newly industrialising countries.

In the 1950s and 1960s, personal services had increased more, in proportion, as well as the iconic goods of the economic boom-household appliances and automobiles—as seen above. Instead, in the following two decades, there was an increase especially in services to businesses (Battilani and Fauri, 2014), in which, however, Italy was not at the cutting edge. Therefore, the growth of these services can hardly be interpreted as an element of modernisation, but as a consequence of the economic crisis: the services sector was viewed as a sort of safety net, capable of absorbing the

However, internationally, there is no common definition of "social enterprise"; in Europe, instead, the concept developed by the EMES network has been broadly accepted, focusing on several characteristics typical of its being an "enterprise", albeit with a "social" mission (Borzaga and Defourny, 2001; Defourny and Nyssens, 2008a). We may summarize the EMES definition as follows: "Social enterprises are not-for-profit private organizations providing goods or services directly related to their explicit aim to benefit the community. They rely on a collective dynamics involving various types of stakeholders in their governing bodies, they place a high value on their autonomy and they bear economic risks linked to their activity" (Defourny and Nyssens, 2008b: 5). This definition has been adopted by the European Commission, with the addition, alongside the terms "enterprise" and "social", of its specific "ownership and governance structure”, with the identification of several key factors (European Commission, 2011; Galera, 2014).

5 "The 1973 oil crisis hit Italy roughly one year later, and was responsible for the only real fall in income during the entire post-war period; in 1975, Italian national income fell by 3.6 per cent" (Zamagni, 1993: 339). 
workers made redundant, as a result of the major reorganisation process by the larger manufacturing companies. The manufacturing sector, in fact, was undergoing a deep transformation (Colli, 1998; Sforzi, 2002; Becattini et al., 2003; Becattini, 2004; Colli and Vasta, 2010 into the "industrial district" model; Rinaldi and Vasta, 2012) ${ }^{6}$ made up of many small enterprises (Bellandi, 1989) concentrated in the so-called "Third Italy" (Bagnasco, 1977) —as the central and north-eastern regions came to be known - with the focus of production shifting to the textiles, clothing and footwear sector and furniture, epitomised by the rising fashion brands and the "Made in Italy" label. The issue at stake was to improve competitiveness in a renewed-increasingly larger and international-market.

This transformation was part of a much broader process that, between the 1970s and the 1980s, resulted in the country's economy and society being dominated by three key concepts: unemployment, rise of the service industry and the welfare crisis.

Firstly, unemployment, consequence of the economic crisis, hit two extreme components of the labour market: young job seekers, mainly female, and workers close to retirement age who risked losing their jobs before they had made the necessary contributions to qualify for a pension. Unemployment was the consequence of the "hot autumn" of 1969 and of the two oil shocks of 1973 and 1979. In the autumn of 1969, in fact, action by the trade unions brought gains for their rank and file, such as wage increases and improved working conditions. However, it also increased the cost of labour and pushed up prices. Likewise, the increased cost of raw materials, particularly of oil, intensified inflationary pressures, which persisted throughout the 1970s and thereafter (Amendola, Salsano and Vecchi, 2011).

Inflation had enormous repercussions on the economy, first and foremost the loss of competitiveness by Italian goods, which negatively affected trade and the balance of payments. The government supported Italian exports on foreign markets by means of a currency devaluation policy, while attempts were made to tackle increasing oil prices by pumping new currency into the economy, with the result of spiralling inflation, which peaked at $18 \%$ in 1978 and $21 \%$ in 1980 (Battilani and Fauri, 2014). Moreover, monetary expansion was no longer possible from 1981, when the Bank of Italy became independent of the Treasury. This put a stop to the practice whereby the Bank of Italy was forced to finance the budget deficit by printing new money to buy the government bonds that the State was unable to sell on the market. Rising inflation was tackled by adopting highly restrictive economic and monetary policies. But these measures did little to bring inflation back to normal levels. Instead, they triggered stagflation, a fall in demand, and a general

\footnotetext{
6 "The sense of belonging to a community is one of the characteristic features of these districts, as is the importance of the family, not only as a consumer unit but also as a producer, with an important interrelationship existing between productive activity and daily life. The organization of the district is not the responsibility of a hierarchical mechanism, but is carried out through market mechanisms and various unwritten local rules. Conglomeration favours the rapid spreading of innovation through the circulation of information and also labour — the labour-force being highly skilled in terms of both ability and knowledge pertinent to the working processes that characterize their industrial district" (Zamagni, 1993: 352).
} 
slowdown of the economy, and-as said-a worrying increase in unemployment.

Yet other aspects characterised Italian politics and economics in this period: besides a rather fragile production system, which is a typical feature of the Italian model of economic development ${ }^{7}$, there was a shift in the average demand of products by households. The demand for the symbolic goods of the economic boom period_refrigerators, washing machines, TV sets and automobilesdropped proportionally, with an increase in the demand for personal services, relations, affection and closeness.

In 1979, a survey on poverty conducted by the Censis research institute identified the characteristic traits of a society undergoing transformation (Censis, 1979). The survey recorded the advent of so-called "post-materialistic poverty" or "new poverty" (Borzaga and Ianes, 2006; Ianes, 2009). Having satisfied the basic needs, such as food and durable and material goods, new non-material needs were emerging in Italian society. The new poverty included such aspects as mental and physical disabilities and all the other conditions produced by the more or less chaotic urban peripheries, such as the abuse of alcohol and drugs, a social evil that towards the end of the 1970 s witnessed an exponential rise in the number of heroin addicts. This "new poverty" signalled the solitude of a significant part of the population, especially the elderly. They were entirely novel conditions, no longer linked to the condition of the working classes and peasants during the first Industrial Revolution, but resulting from a social condition primarily affected by relational issues. It was linked to the difficulties many people experienced in establishing positive relationships.

A revolution was under way also with regard to the world of women. The "housewife" stereotype was being increasingly challenged and family sizes were shrinking. These smaller families could no longer cope with certain tasks "at home", such as child minding and looking after the elderly, as had been the case before then.

New needs also arose from the achievement of certain social advances: for example, Law 180/78 (the so-called Basaglia Law), which ordered the closure of all mental asylums in the country. However, closing these institutions did not mean that the problem of mental illness had been solved, but merely transferred to society as a whole.

The Italian welfare state, built from the mid-20th century, proved unable to tackle this new situation with the required speed. It struggled to set up a safety net of social support capable of addressing these forms of social malaise, primarily related to the psychological universe of persons (Borzaga, 2004; Ianes, 2009).

This fragility, write Alessandro Nuvolari and Michelangelo Vasta, is deeply-rooted in Italian history: "The Italian pattern of modern economic growth is [...] a peculiar one, structurally characterized, on the one hand, by limited investments in $\mathrm{R} \& \mathrm{D}$ activities and in the broader educational system, and, on the other hand, by a limited capacity of generating innovations and being comparative in high tech industries [...] Italy's position among the richest countries of the world is not to be regarded as firmly secured. [...] In fact, the Italian model of development characterized by a scarce attention to innovative performance and by an in-built tendency to rely on a compression of the dynamics of real wages appears as an inherent fragile construction" (Nuvolari and Vasta, 2012: 28-29). 
The fragility of the public sector was, above all, of an organisational nature. The public welfare system was bound down by red tape and standard procedures and was, therefore, unable to meet the needs of users demanding proximity, tailored responses and relation-based actions. It even struggled to keep up with its routine day-to-day operations: a more effective national health service was completed only in 1978.

Yet these were years in which public spending skyrocketed, primarily because of an excessively generous pension system, bloated for electoral reasons, which reached an all-time high in 1973 when public-sector female employees were granted the right to retire after having paid national insurance contributions for only 14 years, six months and one day (Conte, Rossi and Vecchi, 2011). This meant that, between 1973 and 1990, the percentage of public spending for pensions rose from $12 \%$ to $17 \%$ of the GDP (Battilani and Fauri, 2014) "This was so much so that in 1997, although Italian social expenditure was lower than the European average with respect to GDP, social pensions expenditures amounted to 15.8 per cent of the GDP, as opposed to the European average of 12 per cent" (Borzaga and Santuari, 2001: 169).

Overall, in 1990, public spending accounted for $53 \%$ of the GDP. The increase was undoubtedly also due to the rise in the number of public-sector employees, although a very important role was played by the widespread patronage and corruption of the 1980s, which led to the "Republic of political parties" (well-illustrated in a book by a famous historian (Scoppola, 1997), giving rise to a system dominated by vote- buying and by the use of power aimed first and foremost at maintaining voter support. This process peaked in 1970 with the establishment of regional governments, which caused the national debt to soar exponentially, in proportion to the GDP, from $57.7 \%$ in 1979 to $99 \%$ in 1990 , to about $125 \%$ in the following years.

The welfare state was the first to suffer serious injuries, because it could not be expanded without further increasing taxation, already seriously jeopardised by a high level of tax evasion. In fact, "the [...] increase in public spending was not met, however, by a tightening of fiscal measures, which politicians at the time thought would have been best left to a later date, when the social ferment of that moment had died down"(Zamagni, 1993: 338).

\section{Social co-operation: product and process innovation}

The public sector was unable to adequately respond to the problems posed by drug addiction, mental malaise, alcoholism, the caregiving needs of children and the elderly. As seen above, this was primarily due to organisational shortcomings - excessive standardisation of services-and financial aspects, against the backdrop of a welfare system that was focused more on paying out pension benefits than providing services (Borzaga and Ianes, 2006). "The only social services provided on a large scale by the Italian welfare system were education and healthcare-both supplied mainly by public institutions" (Borzaga and Santuari, 2001: 169). 
Little action was taken in response to the difficulty of the state, but one initiative arose from that part of society most sensitive to new poverties, having acquired critical awareness from firstperson experience of the upheavals of 1968, or of the Vatican Council II, which had contributed to renewing the Church (Ianes, 2008) ${ }^{8}$. The Italian co-operative movement itself was strongly idealistic, stemming from two important cultural traditions: the Catholic co-operatives grouped in the political and trade association called "Confcooperative", and the Socialist and Communist inspired co-operatives united in the National League of co-operatives and mutual societies (Lega nazionale delle cooperative e mutue) (Zamagni and Battilani, 2010; Ianes, 2013).

During the 1970s, social activists within this cultural context set up a number of voluntary schemes that lately demonstrated to be the initial step toward more structured and emancipated organisational solutions. Indeed, the crisis of the welfare state was not temporary but definitive, and it could not be resolved with the usual tools of the public welfare system (Borzaga, Poledrini and Galera, 2017).

Given the State's by now definitive inability to provide these services, it became increasingly necessary to rely on the voluntary sector, which, however, required a new legal framework for officially recognising the role of volunteers and regulating the hiring and remuneration of qualified workers.

These early volunteers consequently examined Italian law for a legal arrangement that could give greater stability and continuity to a production of services that had been provisional since the first schemes of organized voluntary work. In other words, they sought to identify a legal form able to reconcile two apparently incompatible aspects: solidarity and entrepreneurship. However, few solutions were forthcoming: according to the Italian civil code, associations and foundations, for example, could not undertake business activities?

Associations, in particular, were not allowed to hire paid employees on a permanent basis, while foundations, by their very nature, were not allowed to provide services. Their task, in fact, was to ensure the growth of their endowment funds for the specific purposes set out by their founding members. The only legal form able in some way to reconcile being business-like (that is, an efficient organization) with fiduciary relationships in pursuit of the community's general interest was the co-operative enterprise.

8 Carlo Borzaga writes on the matter: "The promoters [...] were groups of Catholic volunteers motivated by a belief in the importance of social commitment, as well as groups of parents and groups of practitioners in search of social policies as alternatives to institutional ones" (Borzaga, 2001: 185).

9 According to the Italian legal system the organisations envisaged in Book I of the Civil Code differed from those envisaged in Book V: "In the former, associations and foundations, which are the only two non-profit organisations provided for by the Civil Code, were conceived as pursuing ideal purposes, i.e. they should not have economic goals and activities or, at most, only marginal ones. By contrast, companies and corporations, which also include co-operatives, the aim of which was to secure profits or benefits for their owners. The Civil Code does not envisage the carrying out of productive activities, such as the provision of social services, by using not-for-profit organisational form" (Borzaga and Santuari, 2001: 169). 
The first more or less conscious form of social co-operative is thought to date back to 1963 , when in the north Italian town of Brescia the "San Giuseppe" co-operative was established for the purpose of meeting the needs "of those who have less, but above all of those who are less" (Borzaga and Ianes, 2006: 99), in the words of its founder Giuseppe Filippini. This institution was particularly successful, although it did not inspire any emulators, at least not until the mid-1970s, when the formula attracted renewed interest, primarily for the reasons illustrated previously: the welfare crisis, the emergence of new forms of poverty, growing unemployment, rising drug addiction and mental malaise. Problems that, in the 1970s and 1980s, took on a wholly new dimension and-as we have seen-were initially tackled by the voluntary work sector and only later by social co-operation. Therefore, "several voluntary or advocacy organisations transformed themselves into co-operatives, or they established co-operatives" 10 .

Initially, social co-operation took on a number of different forms, depending on the circumstances, as social solidarity co-operatives, social services co-operatives and integrated production/work cooperatives. The latter were effectively production and work co-operatives, where disabled and nondisabled people worked side by side, united by a bond of solidarity: each worker received equal pay, but contributed to the enterprise according to his or her skills and capabilities. Social services co-operatives, instead, which also qualified as work co-operatives, emerged as a result of the freeze on recruitment in the public social and health care sector. In this case, qualified practitioners, mostly educators and social workers, decided to exploit their skills on the "market" by setting up cooperatives providing social services. The social solidarity co-operatives have yet another story, being established to provide social and care services not to their members but primarily to third parties, thus involving volunteers, workers and users.

Although each of these three types of co-operatives had differing original features, the social solidarity co-operatives had the most significant effects. The innovative potential of this form of co-operative, in fact, is clearly signalled by its capacity to break with the tradition of the Italian co-operative movement. Social solidarity co-operatives, in fact, went beyond the boundary of a mutual aid society whose mission was to meet the needs of its members, by adopting a wholly new approach for a co-operative, pursuing the general interest of the community. Until then cooperatives had been viewed as enterprises that, although they did not aim at maximising their profit, operated for the purpose of benefitting their members, to a greater or lesser degree. Secondly, these co-operatives ended up significantly reforming the ownership structure: from single- to multistakeholder, involving workers, volunteers and the recipients of the services (Borzaga and Tortia,

\footnotetext{
10 "From the first research on this kind of co-op, carried out in 1986 [...] it appears that of the 496 co-operatives surveyed, 22.6 per cent had been formed by voluntary organisations and 15.9 per cent by associations. Only 50 per cent of co-operatives had been established as co-operatives from the outset. With regard to members, only 27 per cent were paid workers, whereas the rest were volunteers directly engaged in the activity, and more generally, supporting members. Only 21 per cent of the co-operatives surveyed did not have volunteers in their membership (in the northern regions, this proportion was 10 per cent)" (Borzaga and Failoni, 1990; Borzaga and Santuari, 2001: 170).
} 
2010 $)^{11}$. Therefore, social solidarity co-operatives included paid workers who provided their skills in exchange for a salary; the volunteer members, who joined the co-op to dedicate a part of their spare time to a project they felt was useful for the community at large; and the member consumers, who obtained a personal benefit from the co-operative. Clearly, social solidarity co-operatives did not have a homogeneous membership, as in the other types of co-operatives, such as production co-operatives, consumer co-operatives, or co-operatives set up to process or market agricultural produce, but a varied membership whose interests and aspirations differed to a certain extent, although they all shared the common goal of collectively pursuing the common good (Borzaga and Ianes, 2006; Poledrini, 2018).

The process was neither simple nor painless. The first social service co-operatives, in fact, often had ratification of their statutes denied by the courts on the ground that they breached the principle of mutuality, so that the co-operatives could not become operational ${ }^{12}$. As seen, the benefits of these co-operatives could be felt primarily outside the co-operatives themselves, often in favour of people who lacked mental capacity and who could not, therefore, form or become members of a cooperative. Furthermore, as said, the membership was not homogeneous but diversified, producing a multi-stakeholder type of organisation (Poledrini, 2018).

Two devices were used by social entrepreneurs to gain recognition as co-operatives. The first consisted in appealing invoking article 45 of the Italian Constitution, which recognizes the "social function" - and not solely mutualistic — of the co-operative enterprise. The second stratagem exploited an expression - "external mutuality" or "enlarged mutuality" - coined to extend the concept of mutuality from the exclusive interest of the co-operative's members to the general interest of the community. Thanks to these two devices, the first social service co-operatives obtained provisional permission to operate from the courts, which, on re-examining their statutes revised their opinions and ratified the statutes.

Yet, all this was a contrivance: these new co-operatives were neither mutualistic nor homogeneous. The benefits deriving from business-like management accrued largely outside the membership. Moreover, many of these organizations involved people with diverse aspirations: the social structure became multi-stakeholder. The business risk was assumed, as said, by stakeholders with differing aspirations and goals.

11 Generally speaking, Borzaga and Mittone distinguish between multi-stakeholder non-profit (MSNP) and limitedprofit (MSLP) organisations. "These organisations are the most recent among all those considered and their distinctive feature is the complex structure of the membership, which can include both consumers and workers as well as volunteers and even representatives of public bodies. A possible example of an MSNP is an association within which workers collaborate with volunteers to provide free services to disadvantaged people, and both categories (workers and volunteer representatives) sit on the controlling board. Examples of MSLP are provided by worker, volunteer and consumer cooperatives, like the Italian social cooperative" (Borzaga and Mittone, 1997: 16).

12 See, for example: A. Scalv., Omologhe e disegni di legge, fasc. cooperativa "il Cammino", Diniego di omologa, Brescia, 18 febbraio 1986; A.Scalv., Omologhe e disegni di legge, fasc. cooperativa "la Bottega”, Diniego di omologa, Brescia, 27 marzo 1986; A.Scalv., Omologhe e disegni di legge, fasc. cooperativa "il Girasole”, Diniego di omologa, Brescia, 15 luglio 1986. 


\section{Legal recognition and different approaches of Confcooperative and the National League of co-operatives and mutual societies}

Awareness of the different nature of this new co-operative with respect to the traditional form stimulated a debate that lasted for fully ten years, and on conclusion of which the approval of law 381/1991 gave social co-operatives a specific status and a recognized space of action. The greatest difficulty was finding a compromise on the issue of voluntary work. In the Catholic social cooperatives, supported by Confcooperative, volunteers played a significant role, because of which they campaigned in favour of a membership law providing that at least $25 \%$ of all members should be volunteers. Instead, the red co-operatives grouped in the League, wanted to keep the number of volunteers as low as possible, because they limited job opportunities, so they campaigned for a volunteer membership ceiling of $40 \%$ of the entire social co-op membership. Finally, after much debate, a compromise was found and Law 381/1991 was introduced, which contemplated not a minimum volunteer membership requirement, but a ceiling, which, however, was set at $50 \%$-not $40 \%$ - of the membership.

The social co-operative was recognized as an organization delivering services of collective interest with the purpose of pursuing the general interest of the community ${ }^{13}$. In particular, article 1 of the law envisaged two possible types of social co-operation: "A-type" co-operation, concerned with the "management of social, health and educational services", and "B-type" co-operation, concerned with integrating disadvantaged persons into work through the management of various activities: agricultural, commercial and industrial, as well as others like the management of services (Borzaga and Ianes, 2006).

As observed by Marco Maiello (1998: 338-339), social co-operatives do not pursue any private interests, but those of the community. "It is recognised that a private individual, as an entrepreneur, produces and sells goods and services not so much in order to pursue his or her own interests as to achieve an objective of a collective nature. It should be emphasised that a co-operative does not lose its private nature by adopting a public one, but it is explicitly called upon to follow the "social function" recognised by the Italian Constitution (Section 45)" [...]. Finally—Maiello highlights_"section 1 of the law appears to go beyond the concept of benefiting members, which traditionally characterised the co-operative movement. The principle of benefiting members recognises that categories or groups of individuals share similar interests that can be furthered by working together in mutual agreement. The implementation of this principle in a commercial form represents the distinguishing feature of ordinary co-operatives. For social co-operatives the situation is somewhat different: its commercial activities are directed at its aim of providing benefits for the community and thus are not for the good of specific groups or categories but are of benefit to society as a whole".

13 According to Law 381/1991, social co-operatives operate "for the general benefit of the community and for the social integration of citizens". 
From this point of view, social co-operatives may be considered innovative enterprises from two points of view: they introduced innovation in both products and goals (social and care services and the general interests of the community), and processes (changes in ownership, favouring the multistakeholder approach). Law 381 introduced the novel idea in Italy that a business may not only seek profits but also pursue the "common good", deliver social services, and actively engage in social policy delivery. It countervailed the traditional conception of an enterprise: as for-profit, first of all, but also co-operative in the strictly mutualistic sense as management of services only for members.

Historically, the two major groupings of Italian co-operatives supported two distinct approaches to social co-operation, relying on their respective leverage: the Catholic tradition grouped in Confcooperative and the "red" tradition, organised as the National League of cooperatives and mutual societies (Lega nazionale delle cooperative e mutue), which changed its name in 1996 to Legacoop. The member co-operatives of Confcooperative have privileged a network model known as the "strawberry field", consisting of many small geographically widespread social co-operatives, the key strong point of which is an in-depth knowledge of the communities within which they operate and for which they can therefore provide tailored solutions. They do not necessarily ignore the advantages of larger organisations, but feel that they must not necessarily grow, preferring instead to form a network consisting of provincial consortiums and a national consortium named after Gino Mattarelli (Cgm). On the contrary, the Lega member co-operatives have developed into larger organisations with many employees, offering a range of services in different sectors and geographical areas. The medium-to-large size of these co-operatives has enabled them to achieve economies of scale and to rely almost exclusively on their own resources, in order to cut back on costs without having to set up a consortium. The risk, however, in this case, was an impairment of the original co-operative and community focus (Battilani and Schröter, 2012).

Each approach obviously featured strengths and weaknesses, although in recent times there has been a "combination" of the two, in an attempt to reconcile community rooting and efficiency. This has led to the development, within Confcooperative, of large-scale co-ops and the presence in Legacoop of smaller organisations (Borzaga and Ianes, 2011).

This co-operative model has been especially popular from the 1990s onwards, after the increasing withdrawal of the public sector from the welfare system. This has led to a boom of the social private sector, and of social co-operatives, which have started providing social care services or helping disadvantaged people to enter the labour market, through the creation of partnerships with the public sector or by winning procurement contracts, thus overcoming the limitations and inefficiencies of the government. The approval of Laws 142 and 241 in 1990, later amended, has further driven this process. These regulations devolved most social and health care services to the regional governments, which, in turn, have been able to outsource them to third parties, including social co-operatives. Therefore, while at the beginning the first social projects undertaken by these organisations could receive no adequate support from government, following the approval, in 1990, of the two above mentioned laws, and of Law 381/1991, it was possible to create 
an institutional and legal framework within which the public and private sectors could work together as partners, fostering the growth and development of social co-operatives. Moreover, the recent "fiscal compact" could also positively affect the development of these organisations, because the European Union requires Member States to reduce government indebtedness, with the introduction of tight budgetary constraints, with further cuts in government spending and the provision of services by the public sector.

Overall, the awarding of social services contracts to social co-operatives, under tendering and procurement proceedings, has shown itself to be a good solution, because it can offer tailored services closer to the community, and remedy certain pockets of inefficiency in the public sector, while at the same time managing to cut back on spending. The generalised downscaling of the welfare state, which is taking place in most European countries, and the transition to the so-called "welfare society", has, of course, produced and produces a number of criticalities and some rather unfair aspects. Examples of this are the cases of low wages paid, in some cases, to the employees of social co-operatives, although - it must be admitted - an extensive literature proves that the low wages are compensated by a higher degree of satisfaction of the co-op operatives, who identify with the social mission of their organisation because they are inherently motivated (Frey, 1997; Borzaga and Tortia, 2010; 2015). This, however, is not always true, as highlighted by the recent episodes of corruption that have involved several social co-operatives, in particular the Rome-based "29 giugno" co-operative and several sectors of the Rome government, in respect of some rather dubious and hardly transparent dealings in terms of procurement procedures, and the poor use of public money this entailed. Therefore, the problem of fake co-operatives, set up by unscrupulous people simply to take advantage of tax benefits, who could not care less for the spirit and mission of real co-operatives, also applies to social co-operatives. This phenomenon could contaminate the entire co-operative movement, so the two major co-operative umbrella organisations-Confcooperative and Legacoop-have collected signatures for a people's bill called "Stop the false co-operatives", designed to prevent wrongdoers from using the co-operative spirit for all the wrong reasons, simply to pursue personal interests, while violating the law and defrauding the central State.

\section{Quantitative aspects}

The evolution just described has been reflected in the quantitative aspects of the growth of social co-operatives. The first survey on the phenomenon was conducted in 1987, and it already highlighted the characteristic features of these organizations, but also their potential for growth and development. As of 31 December 1986, the 496 co-operatives surveyed had 4,265 voluntary members. There were also 4,057 worker members, 2,277 non-member volunteers, and 704 employees. To these were added 2,412 disabled members, and the 22,684 users of the services supplied by the co-operatives (Borzaga and Failoni, 1990). 
At the time of approval of law 381/91, which regulated social co-operatives, co-operatives were estimated at just over one thousand in number. The figure rose to around three thousand in the mid-1990s, and then grew further to 7,363 as of 31 December 2005, as reported by the Italian National Institute of Statistics (Istat) survey (see Tables 1 and 2).

Table 1. Number of co-operatives and value of output by type (2003-2011)

\begin{tabular}{|c|c|c|c|c|c|c|c|c|c|c|c|}
\hline & \multicolumn{5}{|c|}{2003} & \multicolumn{5}{|c|}{2005} & \multirow{2}{*}{$\begin{array}{c}2011 \\
\text { Tot. }\end{array}$} \\
\hline & A-type & B-type & $\begin{array}{l}\text { (Mixed } \\
\text { A+B- } \\
\text { type) }\end{array}$ & $\begin{array}{l}\text { Consortia } \\
\text { of co-ops }\end{array}$ & Tot. & A-type & B-type & $\begin{array}{l}\text { Mixed } \\
(\mathrm{A}+\mathrm{B}- \\
\text { type })\end{array}$ & $\begin{array}{l}\text { Consortia } \\
\text { of co-ops }\end{array}$ & Tot. & \\
\hline Co-ops (N.) & 3,707 & 1,979 & 249 & 224 & 6,159 & 4,345 & 2,419 & 315 & 284 & 7,363 & 11,264 \\
\hline $\begin{array}{l}\text { Value of output } \\
\text { (million EUR) }\end{array}$ & 3,107 & 1,020 & 169 & 530 & 4,826 & 4,133 & 1,354 & 215 & 680 & 6,382 & n.a. \\
\hline
\end{tabular}

Source: our calculations on data from Istat $(2006 ; 2007 ; 2011)$.

Table 2. Human resources, users and disadvantaged users of social co-operatives (2003-2011)

\begin{tabular}{lcrr}
\hline & $\mathbf{2 0 0 3}$ & $\mathbf{2 0 0 5}$ & $\mathbf{2 0 1 1}$ \\
\hline Volunteers & 31,879 & 34,626 & 42,368 \\
Paid personnel & 189,134 & 244,223 & 320,513 \\
Users of A-type co-ops & $2,403,245$ & $3,302,551$ & n.a. \\
Disadvantaged personnel of B-type co-ops & 23,587 & 30,141 & n.a. \\
\hline
\end{tabular}

Source: our calculations on data from Istat $(2006 ; 2007 ; 2011)$.

Over $70 \%$ of the more than seven thousand co-operatives surveyed in 2005 had been constituted since 1991, a figure indicative of the recent development of the phenomenon and its exponential growth-as noted by Istat-especially in the period 1996-2000. Out of the total of 7,363 cooperatives, $59 \%$, equal to 4,354 units, belonged to the A-type category, in that they delivered social, health and educational services, whilst 32.8\%, corresponding to 2,419 co-operatives, were of B-type, and were therefore engaged in the work integration of disadvantaged persons. There were then 315 co-operatives which were mixed, in that they undertook the activities foreseen for A-type and B-type co-operatives, although, as will be seen, there were relatively few of them. Finally to be mentioned are 284 consortia, which represented $3.9 \%$ of the total. In 2003, co-operative members numbered 262,389, of which 255,583 were physical persons and 6,806 legal persons, a $19 \%$ increase on 2003. Another interesting finding with regard to the social base of co-operatives concerns the diverse types of members of which they were composed, and the consequent diverse forms of ownership. The survey results show that $81.1 \%$ of co-operatives associated several categories of stakeholders, although only $21.1 \%$ had more than three of them. This confirms a distinctive feature of the phenomenon: the ownership form mostly frequently assumed by social co-operatives 
is of the multi-stakeholder type, even though the number of categories represented is small.

With reference to economic aspects, in 2005 the social co-operation movement achieved an output amounting to around 6.4 billion EUR, assuring paid employment for 244 thousand workers and involving more than 34 thousand volunteers. The sector is largely female, given that $71.2 \%$ of its personnel are women. Inspection of the main activities undertaken and the composition of users shows that in 2005 the majority (59.1\%) of A-type co-operatives delivered social assistance, particularly in the home (36.5\% of co-operatives) and largely in the form of childcare, which accounted for $28.8 \%$ of users. B-type co-operatives were mainly concerned with the work integration of persons with physical, mental or sensorial disabilities. In 2005, the users served by A-type co-operatives numbered more than 3.3 million, a $37.4 \%$ increase on the 2003 figure. B-type co-operatives involved 30,141 disadvantaged persons in work entry schemes, recording a $27.8 \%$ increase with respect to 2003 .

Unfortunately, the latest Istat figures relating to the 2011 census, are not as detailed as other statistical surveys. In any case, they show that, in the census year there were 11,264 social cooperatives employing 320,513 people, plus 43,082 external workers and 42,368 volunteers.

This brief statistical survey testifies to the presence of a phenomenon that, though limited with respect to the economic system as a whole, achieves levels of performance and growth, in terms of employment, services delivered, and users, often several times higher than those recorded by other business forms. This has enabled the social co-operative movement to put itself forward as an actor able to furnish satisfactory responses within Italian social policies.

\section{From Italy to Europe: the different degrees of social enterprises}

The original nature of social co-operatives in Italy, as a prototype of social enterprises in Europe, can be measured - as we have seen - not only by the dimensional growth of the phenomenon, but also by observing the interest raised by this formula in other European countries. In many of these, similar organisations were set up and then adequately regulated. Social enterprises were therefore "institutionalised" across Europe according to two distinct approaches. In some countries, based on the Italian model and Law 381/91, the co-operative form was used as a blueprint, albeit adapting it to the production of social services and the work integration of disadvantaged people. Like in Italy, the legislators in these countries intervened later on, simply ratifying a phenomenon that had sprung up from the grassroots. This means that practice has defined the prototype of the social enterprise, although the subsequent legal recognition has enabled its institutionalisation and subsequent growth in numbers. In these cases, civil society has proved more proactive than politicians, confirming the bottom up approach prevalent in this sector. In other cases, however, social enterprises were given a specific legal form, in an attempt to differentiate them from the cooperative (Galera and Borzaga, 2009; Galera, 2014). Generally speaking, "social enterprises were initially established as associations in those countries where the legal form association allows for 
a degree of freedom in selling goods and services on the open market [...]. In countries where associations are more limited in this regard, such as the Nordic countries and Italy, social enterprises were more often created under the legal form of co-operative. Co-operatives are more interesting as they have a clear entrepreneurial nature" (Galera and Borzaga, 2009: 218).

This resulted in social enterprises being assimilated to co-operatives in Portugal, Spain, France, Greece, Czech Republic and Croatia, while in Belgium and the United Kingdom they were given the opportunity to take on a broader range of legal forms. This latter solution was also adopted by the more recent law on social enterprises in Italy (Legislative Decree 155/2006), which now complements-without replacing it-the previous law on social co-operation (Law 381/1991) (Borzaga, Poledrini and Galera, 2017).

Looking into some of the most representative cases, in 1998 Portuguese legislators embarked on the reorganisation of the entire sector introducing the Cooperativas de solidariedade social, which grouped both the supply of services and the work integration of disadvantaged persons (Perista, 2001; Perista and Nogueira, 2006). Spain followed suit, in 1999, with a national law on Cooperativas de iniciativa social, focusing on both education and social and health care, while a dozen Regions introduced regulations for work integration co-operatives (Vidal, 2001). In France, the law establishing the Société Coopérative d'Intérêt Collectif (SCIC) was passed in 2001 to regulate co-operatives with an explicit social mission, featuring, inter alia, democratic governance mechanisms. Moreover, the members of SCICs are required to belong to at least three different groups of stakeholders, but always including users and workers (Fraisse, 2008). More recently, in 2006, Poland introduced a form of social co-operative aimed at the social and work integration of disadvantaged persons: at least $50 \%$ of the workforce of these co-operatives must be affected by a mental or physical disability (Leś, 2004; 2008). Even more recently, various types of social co-operatives have been introduced in Greece, the Czech Republic and Croatia, although the process is still ongoing. The latter are all variations of the Italian model.

The case of Belgium is a different story. Here, social enterprises were not linked to the social cooperative, but "new legal brands for social enterprises" (Borzaga and Galera, 2014) were introduced. Since 1995, in fact, articles 661-669 of the Belgian Civil Code provide that all businesses may qualify as Societé à finalité sociale, provided that they comply with certain conditions (Nyssens, 2008). In particular, this type of enterprise must be non-profit making, must not distribute profit except to a very limited extent, and they must specify their role as combating social exclusion (Defourny and Nyssens, 2001) ${ }^{14}$. In addition, Galera and Borzaga (2009: 221) write, "the enterprise must produce a special annual report indicating how it went about achieving its welfare goals; any member of staff must be allowed to become a partner after a year of commitment to the enterprise; any member of staff who terminates a work contract loses his status as a partner; in the event of liquidation, any surplus, after all liabilities have been met and the partners have been reimbursed for their outlay, is allocated in keeping with the enterprise's welfare goal (it has to be given to another société à finalité

\footnotetext{
14 "This legal status has met with only limited success since it brings with it a considerable number of requirements in addition to those associated with the tradition company" (Defourny and Nyssens, 2001: 47).
} 
sociale or association sans but lucrative)". Due to the complexity of the requirements, this legal status was adopted, between 1996 and 2006, by no more than 400 enterprises. It is moreover worth noticing that the articles of the Belgian Civil Code providing that all businesses may qualify as société à finalité sociale have been repealed in 2019. A national accreditation scheme that is applicable only to co-operatives was introduced, which enables the identification of co-operatives that pursue explicit social aims (European Commission, 2020).

As mentioned above, Great Britain and Italy too have extended the qualification of "social enterprise" to a range of different types of organisations, based on their having certain characteristics. In Great Britain, for example, Community Interest Companies (CICs) are private limited companies regulated by the Commercial Code. They can carry on any type of business, provided that this is done in the interest of the entire local community, in favour of which any profit should also be reinvested. Before qualifying and being allowed to operate, these companies must pass a Community Interest Test. Each CIC must provide specific guarantees with regard to the assets it owns, which must be tied to a social purpose. They must also deposit an annual Community Interest Report on the activities carried out. The CICs do not have tax benefits, but are subject to simplified rules compared to other organisations, and may finance themselves by issuing shares on the market, thanks to the possibility of remunerating them with a small distribution of profit (Regulator of Community Interest Companies, 2007; Spear et al., 2009).

Finally, regarding Italy, social co-operatives had already been regulated by Law 381/91, but since then complementary — and not replacement — provisions have been introduced, with regard to social enterprises (Law 118/2005, perfected by Decree 155 of 2 March 2006) (Fici and Galletti, 2007). The aim of the new law was to further free the potential expressed by social co-operatives by removing certain limitations. This has been done by moving in two directions. On the one hand, the range of activities that can be carried out by social enterprises has been extended, way beyond social services (A-type social co-operatives) and the work integration of disadvantaged persons (B-type social co-operatives). In particular, the law accurately identifies the goods and services that social enterprises may produce. They include education and training, environmental protection, the valorisation of the cultural heritage, social tourism, research, cultural services and out-of-school training. On the other hand, the law provides that all organisations, associations and businesses recognised by the Civil Code may qualify as "social enterprises", provided that they comply with certain specific rules. Therefore, besides social co-operatives, other types of organisations may pursue general interest objectives, and therefore call themselves "social enterprises", such as traditional cooperatives, associations, foundations, private and public limited companies ${ }^{15}$. These must be private companies, not controlled by a public or for profit entity, they must be established for non-profit purposes and feature mechanisms for fostering participation by users and employees, and their

15 To measure the size and diffusion of social enterprises in Italy, several important research reports have been conducted: Borzaga and Zandonai (2009), Venturi and Zandonai (2012). 
management must be based on criteria of efficiency and transparency, with the obligation to file an annual social report. In 2013, there were 1,348 social enterprises registered according to Decree $255 / 2006$, plus over 12,000 social co-operatives, which also qualify as social enterprises.

At the end of year 2003, also Finland adopted a social enterprise law, which acknowledged social enterprises aimed at facilitating the integration to work of disadvantaged people ${ }^{16}$. This shows one thing: Italian B-type social co-operation, which facilitates the integration to work of disadvantaged people, has come before other similar experiences born in Europe. Thus, countries like Slovenia and Lithuania have also decided to acknowledge social enterprises by introducing specific legislation.

As seen, the comparison between the different types of social enterprises established in Europe over the last few decades shows differences and variety. Alongside the inevitable specificities, however, they do have some things in common. For example, the fact that they are set up by groups of citizens who take it upon themselves to provide for needs that should be covered by government programs; needs that have been strongly considered by these people and to satisfy which they have set up grassroots social solidarity initiatives. Subsequently, these same citizens have started considering the idea of producing, on a stable and entrepreneurial basis, goods and services for the benefit of the community, forming various types of social enterprises serving the entire community.

Among these, in particular, the Italian social co-operative may be interpreted as the outcome of a process of institution building, starting as the entrepreneurial strengthening of the existing associations founded by volunteers, in the wake of the first step in confronting and tackling the crisis of the welfare state. Later on, as in the case of Italy and the United Kingdom, social enterprises integrated the traditional welfare services with more innovative services, penetrating new fields of activity of interest for the community.

Observing the dynamics in the single countries, however, it does not seem possible to establish a positive relationship between the weakness of the public welfare system and the considerable development of social enterprises. In a country like Sweden, for example, which has a universal welfare system, there is also a significant tradition of activism by the civil society and social enterprises (Pestoff, 2009), while in other countries, such as Austria and Germany, which have developed particularistic welfare systems, social enterprises are much weaker.

\footnotetext{
16 For example, "the Finnish Act on Social Enterprise (1351/2003) was [...] adopted at the end of 2003 [...] and came into force on January 1, 2004. According to this Act, a social enterprise: - is an enterprise created for the employment of people with disabilities and of the long-term unemployed; - is a market-oriented enterprise with its own products and/or services; - should be registered as a trader in the register of social enterprises kept by the Ministry of Labour; - should pay all its employees (whether disadvantaged or not) wages according to the general agreements currently in force in its branch of industry. Moreover, the bylaws of the enterprise must explicitly mention the aim to employ disabled and long-term unemployed persons; the disabled and the long-term unemployed disabled must represent at least $30 \%$ of the social enterprise's total workforce, and every social enterprise in the register must employ at least one disabled person. No other enterprise than those registered may use the words 'social enterprise' in its marketing or in its name" (Pättiniemi, 2008: 17-18).
} 


\section{Conclusions}

According to a historical approach, this article reconstructs the context in which the first types of social enterprises have emerged in Europe: the Italian social co-operative, which is a new enterprise model that achieved a position of leadership in the welfare and social services system. The social co-operative is a new enterprise model, which achieved a position of leadership in the welfare and social services system. A form of co-operative, inter alia, that managed to break with the traditional co-operative movement, to affirm the idea that co-operatives could be established for solidarity purposes besides mutual aid. The added value of social co-operation, therefore, is not mutual benefit but public benefit, also based on Law 381/1991, which became necessary to enable and qualify a type of co-operative company that was not contemplated by the Italian legal system and whose mission was to pursue the general interest of the community rather than the interest of its members (whether disabled or not). This means that practice has defined the prototype of the social enterprise, although the subsequent legal recognition has enabled its institutionalisation and subsequent growth in numbers. In these cases, civil society has proved more proactive than politicians, confirming the bottom up approach prevalent in this sector. This co-operative model has been especially popular from the 1990s onwards, after the increasing withdrawal of the public sector from the welfare system.

All these facts are of historical interest. Nevertheless, social co-operation is especially interesting from a historical point of view because it was the first social enterprise type born in Europe and in the world altogether. Indeed, the experience of Italian social co-operatives has been transferred and adapted by a number of European and non-European countries, and are now universally known with the name of "social enterprises".

\section{References}

Amendola, N., Salsano, F. \& Vecchi, G. (2011). Povertà. In: G. Vecchi (Ed.), In ricchezza e in povertà: Il benessere degli italiani dall'Unità a oggi. Bologna: Il Mulino, pp. 271-317.

Bagnasco, A. (1977). Tre Italie: la problematica territoriale dello sviluppo italiano. Bologna: Il Mulino.

Battilani, P. \& Fauri, F. (2014). L'economia italiana dal 1945 a oggi. Bologna: Il Mulino.

Battilani, P. \& Schröter, G.H. (2012). Demutualization and Its Problems. In: P. Battilani \& G.H. Schröter (Eds.), The Cooperative Business Movement, 1950 to the Present. Cambridge: Cambridge University Press, pp. 150-171.

Bentley, G.B. (1966). The Evolution of National Insurance in Great Britain: The Origins of the Welfare State. London: Joseph Micheal.

Becattini, G. (2004). Industrial Districts. A New Approach to Industrial Change. Cheltenham: Edward Elgar.

Becattini, G., Bellandi, M., Dei Ottati, G. \& Sforzi, F. (2003). From Industrial Districts to Local Development: An Itinerary of Research. Cheltenham: Edward Elgar. 
Bellandi, M. (1989). The role of small firms in the development of the Italian manufacturing industry. In: E. Goodman \& J. Bamford (Eds.), Small Firms and Industrial Districts in Italy. London: Routledge, pp. 31-62.

Borzaga, C. (2001). Italy: The Impressive Development of social Co-operatives in Italy. In: R. Spear, J. Defourny, L. Favreau \& J.L. Laville (Eds.), Tackling Social Exclusion in Europe: The contribution of the social economy. Aldershot: Ashgate, pp. 181-201.

Borzaga, C. (2004). From Suffocation to Re-emergence: the Evolution of the Italian Third Sector. In: A. Evers \& J.L. Laville (Eds.), The Third Sector in Europe. Cheltenham: Edward Elgar, pp. 45-62. DOI: https://doi. org/10.4337/9781843769774.00008

Borzaga, C. \& Defourny, J. (Eds.) (2001). The Emergence of Social Enterprise. London: Routledge. DOI: https://doi. org/10.4324/9780203164679

Borzaga, C. \& Failoni, G. (1990). La cooperazione di solidarietà sociale in Italia, Cooperazione e Credito, 128: 273-297.

Borzaga, C. \& Galera, G. (2014). New Trends in the Nonprofit Sector in Europe: the Emergence of Social Enterprises. In: E. Costa, L.D. Parker \& M. Andreaus (Eds.), Accountability and Social Accounting for Social and Non-profit Organizations. UK: Emerald Group, pp. 89-110. DOI: https://doi.org/10.1108/S1041-706020140000017002

Borzaga, C. \& Ianes, A. (2006). L'economia della solidarietà: Storia e prospettive della cooperazione sociale. Roma: Donzelli Editore.

Borzaga, C. \& Ianes, A. (2011). Il sistema d'imprese della cooperazione sociale. Origini e sviluppo dei consorzi di cooperative sociali, Euricse Working Papers Series, $014 \mid 11$.

Borzaga, C. \& Mittone, L. (1997). The Multi-stakeholders versus the Nonprofit Organisations, Discussion Paper, 7. Trento: University of Trento.

Borzaga, C., Poledrini, S. \& Galera, G. (2017). Social Enterprise in Italy: Typology, Diffusion and Characteristics, Euricse Working Papers Series, 95 |17. DOI: https://doi.org/10.2139/ssrn.3036384

Borzaga, C. \& Santuari, A. (2001). Italy: From traditional co-operatives to innovative social enterprises. In: C. Borzaga \& J. Defourny (Eds.), The Emergence of Social Enterprise. London: Routledge, pp. 166-181. DOI: https://doi. org/10.4324/9780203164679

Borzaga, C. \& Tortia, E.C. (2010). The Economics of Social Enterprises: An Interpretive Framework. In: L. Becchetti \& C. Borzaga (Eds.). The Economics of Social Responsibility: The World of Social Enterprises. London: Routledge, pp. 15-33. DOI: https://doi.org/10.4324/9780203851029

Borzaga, C. \& Tortia, E. (2015). Co-operation as coordination mechanism: a new approach to the economics of cooperative enterprises, Euricse Working Papers Series, 078|15.

Borzaga, C. \& Zandonai, F. (Eds.) (2009). Rapporto Iris Network: L'impresa sociale in Italia: Economia e istituzioni dei beni comuni. Roma: Donzelli Editore.

Brunetti, A., Felice, E. \& Vecchi, G. (2011). Reddito. In: G. Vecchi (Ed.), In ricchezza e in povertà: Il benessere degli italiani dall'Unità a oggi. Bologna: Il Mulino, pp. 209-234.

Carbonell, M. (2012). Montes de piedad and Savings Banks as Microfinance Institutions on the Periphery of the Financial System of mid-nineteenth-century Barcelona, Business History, 54(3): 363-380. DOI: https://doi.org/10.1080/0 0076791.2011 .638486

Censis (1979). Sondaggio sulle povertà. Roma: Censis.

Clark, C. (1951). The Conditions of Economic Progress. London: Macmillan.

Colli, A. (1998). Evidence and Conjectures from the History of the Italian Industrial Districts. In: European Yearbook of Economic History, vol. 1. Aldershot: Ashgate, pp. 75-92. DOI: https://doi.org/10.4324/9780429445576-5

Colli, A. \& Vasta, M (Eds.). (2010), Forms of Enterprise in Twentieth century Italy: Boundaries, Structures and Strategies. Cheltenham: Elgar. DOI: https://doi.org/10.4337/9781849806565 
European Commission (2011). Social Business Initiative Creating a favourable climate for social enterprises, key stakeholders in the social economy and innovation. Communication of the Commission to the European Parliament, The Council, The European Economic and Social Committee and the Committee of the Regions, 25.10.2011 COM (2011) 682 final. Brussels.

European Commission (2020). Social enterprises and their ecosystems in Europe. Comparative synthesis report. Authors: C. Borzaga, G. Galera, B. Franchini, S. Chiomento, R. Nogales and C. Carini. Luxembourg: Publications Office of the European Union. Available at: https://europa.eu/!dK34uG [Accessed: 22 $2^{\text {th }}$ July 2020].

Conte, L., Rossi, M. \& Vecchi, G. (2011). Vulnerabilità. In: G. Vecchi (Ed.), In ricchezza e in povertà: Il benessere degli italiani dall'Unità a oggi. Bologna: Il Mulino, pp. 319-351.

Cornwall, J. (1984). After Stagflation. Alternative to Economic Decline. London: Basil Blackwell.

Defourny, J. \& Nyssens, M. (2001). Belgium: Social enterprises in community services. In: C. Borzaga \& J. Defourny (Eds.), The Emergence of Social Enterprise. London: Routledge, pp. 47-64.

Defourny, J. \& Nyssens, M. (Eds.) (2008a). Social Enterprise in Europe: recent trends and developments, EMES Working Papers, 08/01 (transversal paper). Liège: EMES European Research Network.

Defourny, J. \& Nyssens, M. (2008b). Social Enterprise in Europe: Introduction to an Update. In: J. Defourny \& M. Nyssens (Eds.), Social Enterprise in Europe: recent trends and developments, EMES Working Papers, no. 08/01 (transversal paper). Liège: EMES European Research Network, pp. 4-12.

Douglas, A.E. (1986). The Emergence of the Welfare States. Oxford: Blackwell.

Fici, A. \& Galletti, D. (Eds.) (2007). Commentario al decreto sullimpresa sociale (D.lgs. 24 marzo 2006, n. 155). Torino: Giappichelli.

Fisher A. (1935). The Clash of Progress and Security. London: Macmillan.

Fraisse, L. (2008). France. In: J. Defourny \& M. Nyssens (Eds.), Social Enterprise in Europe: recent trends and developments, EMES Working Papers, no. 08/01 (transversal paper). Liège: EMES European Research Network, pp. 20-21.

Fraser, D. (1984). The Evolution of the British Welfare State. A History of Social Policy since the Industrial Revolution. London: MacMillan. DOI: https://doi.org/10.1007/978-1-349-06939-2

Frey, B. (1997). Not Just for the Money. An Economic Theory of Personal Motivation. Cheltenham, UK/Brookfield, US: Edward Elgar.

Galera, G. (2014). Dinamiche evolutive dell'impresa sociale a livello europeo. Visibilità, replicabilità e stadi di sviluppo, Osservatorio Isfol, IV(3-4): 23-45.

Galera, G. \& Borzaga, C. (2009). Social Enterprise: An International overview of its conceptual evolution and legal implementation, Social Enterprise Journal, 5(3): 210-228. DOI: https://doi.org/10.1108/17508610911004313

Gosden, P.H.J.H. (1961). The Friendly Societies in England 1815-1875. Manchester: University of Manchester.

Hansmann, H. (1980). The Role of Nonprofit Enterprises, The Yale Law Journal, 89(5): 835-901.DOI: https://doi. org/10.2307/796089

Harris, J. (1997). William Beveridge. A Biography. Oxford: Oxford University Press. DOI: https://doi.org/10.1093/ acprof:oso/9780198206859.001.0001

Hennock, P.E. (1987). British Social Reform and German Precedents: the Case of Social Insurance: 1880-1914. Oxford: Clarendon.

Hennock, P.E. (2007). The Origin of the Welfare State in England and Germany: 1850-1914: Social Policies Compared. Cambridge: Cambridge University Press.

Klausen, J. (1998). War and Welfare. Europe and the United States, 1945 to the Present. London: MacMillan. DOI: https:// doi.org/10.1057/9780312299880 
Hoyt, A. \& Menzani, T. (2012). The International Cooperative Movement, 1950 to the Present. In: P. Battilani \& G.H. Schröter (Eds.), The Cooperative Business Movement, 1950 to the Present. Cambridge: Cambridge University Press, pp. 23-62. DOI: https://doi.org/10.1017/CBO9781139237208.003

Ianes, A. (2008). Le radici culturali. In: M. Demozzi \& F. Zandonai (Eds.), Limpresa sociale di comunità. Strumenti per la creazione e la gestione. Trento: Edizioni31, pp. 11-31.

Ianes, A. (2009). La cooperazione sociale come storia d'impresa, Imprese e Storia, 37: 85-130.

Ianes, A. (2011). Le cooperative. Roma: Carocci.

Ianes, A. (2013). Introduzione alla storia della cooperazione in Italia (1854-2011): Profilo storico-economico e interpretazione. Soveria Mannelli: Rubbettino Editore.

Ianes, A. \& Tortia, E.C. (2010). Creativity and Institution building: The Case of Italian Social Cooperatives. In: S. Sacchetti \& R. Sugden (Eds.), Knowledge in the Development of Economies. Institutional Choices under Globalisation. Cheltenham: Elgar, pp. 158-180.

Jones, C. (1982). Charity and Bienfaisance: the Treatment of the Poor in the Montpellier Region: 1740-1815. Cambridge: Cambridge University Press. DOI: https://doi.org/10.1017/CBO9780511562655

Istat (2006). Le cooperative sociali in Italia. Anno 2003, Informazioni, n. 30. Roma.

Istat (2007). Le cooperative sociali in Italia. Anno 2005, Statistiche in breve. Roma.

Istat (2011). Censimento dell'industria e dei servizi. Roma.

Jütte, R. (1984). Poverty and deviance in early modern Europe. Cambridge: Cambridge University Press.

Leonardi, A. (2000). Dalla beneficenza al mutualismo solidale: l'esperienza cooperativa di F.W. Raiffeisen ed i suoi primi riflessi in Italia. In V. Zamagni (Ed.), Povertà e innovazioni istituzionali in Italia: Dal Medioevo ad oggi. Bologna: Il Mulino, pp. 551-583.

Leś, E. (2004). Co-operatives in Poland: from state-controlled institutions to new trends in co-operative development. In: C. Borzaga \& R. Spear, (Eds.), Trends and challenges for Co-operatives and Social Enterprises in developed and transition countries. Trento: Edizioni31, pp. 185-196.

Leś, E. (2008). Poland. In: J. Defourny \& M. Nyssens (Eds.), Social Enterprise in Europe: recent trends and developments, EMES Working Papers, no. 08/01 (transversal paper). Liège: EMES European Research Network, pp. pp. 28-29.

Lewis, J. (1995). The Voluntary Sector, the State and the Social Work in Britain: the Charity Organisation Society/Family Welfare Association since 1869. Aldershot: Elgar.

MacPherson, I. (2008). The Co-operative Movement and the Social Economy Traditions: Reflections on the Mingling of Broad Visions, Annals of Public and Cooperative Economics, 79(3): 625-642. DOI: https://doi.org/10.1111/ j.1467-8292.2008.00373.x

Maiello, M. (1998). Italy. In: C. Borzaga \& A. Santuari (Eds.), Social enterprises and new employment in Europe. Trento: Regione Autonoma Trentino-Alto Adige, pp. 333-366.

Martinelli, F. \& Gadrey, J. (2000). L'economia dei servizi. Bologna: il Mulino.

Mommsen, W.J. (Ed.) (1981). The Emergence of the Welfare State in Britain and Germany, 1850-1950. London: Croom Helm.

Nyssens, M. (2008). Belgium. In J. Defourny \& M. Nyssens, (Eds.), Social Enterprise in Europe: recent trends and developments, EMES Working Papers, no. 08/01 (transversal paper). Liège: EMES European Research Network, pp. 13-14.

Nuvolari, A. \& Vasta, M. (2012). The Ghost in the Attic? The Italian National Innovation System in Historical Perspective, 1861-2011, Quaderni del Dipartimento di Economia politica e statistica, 665, Università degli Studi di Siena.

O'Brien, C. \& Fenn, P. (2012). Mutual Life Insurers: Origins and Performance in pre-1900 Britain, Business History, 54(3): 325-345.DOI: https://doi.org/10.1080/00076791.2011.638483 
Quine S.M. (2002). Italy's Social Revolution. Charity and Welfare from Liberalism to Fascism. New York: Palgrave. DOI: https://doi.org/10.1057/9781403919793

Owen, D. (1965). English Philanthropy: 1660-1960. Cambridge: Belknap press of Harvard University press.

Pättiniemi, P. (2008). Finland. In: J. Defourny \& M. Nyssens, (Eds.), Social Enterprise in Europe: recent trends and developments, EMES Working Papers, no. 08/01 (transversal paper). Liège: EMES European Research Network, pp. 17-19.

Perista, H. (2001). Portugal: Co-operatives for rehabilitation of people with disabilities. In: C. Borzaga \& J. Defourny (Eds.), The Emergence of Social Enterprise. London: Routledge, pp. 192-202.

Perista, H. \& Nogueira, S. (2006). Work Integration Social Enterprises in Portugal: a tool for work integration?. In: M. Nyssens (Ed.), Social Enterprise: At the Crossroads of Market, Public policies and Civil Society. London: Routledge.

Poledrini, S. (2018). The Emergence of new Social Enterprise Models in Italy: First Insights from the International ICSEM Project, Electronic Journal of Management, 2: 1-19.

Pestoff, V. (2009). Towards a Paradigm of Democratic Participation: Citizen Participation and Co-production of Personal Social Services in Sweden, Annals of Public and Cooperative Economics 80(2): 197-224. DOI: https://doi. org/10.1111/j.1467-8292.2009.00384.x

Regulator of Community Interest Companies (2007). Report to the Secretary of State for Trade and Industry. Cardiff: Regulator of community Interest Companies.

Rinaldi, A. \& Vasta, M. (2012). The Italian Corporate Network After the 'Golden Age' (1972-1983): From Centrality to Marginalization of State-Owned Enterprises, Enterprise \& Society, 13(2): 378-413.

Salamon, M.L. \& Anheier, K.H. (1994). The Emerging Sector: The Nonprofit Sector in Comparative Perspective: An Overview. Baltimore: John Hopkins University.

Scoppola, P. (1997). La repubblica dei partiti: Evoluzione e crisi di un sistema politico 1945-1996. Bologna: Il Mulino.

Sforzi, F. (2002). The Industrial District and the 'New' Italian Economic Geography, European Planning Studies, 10(4): 439-447. DOI: https://doi.org/10.1080/09654310220130167

Sneider, T.M. (2000). Charity and property. The wealth of opere pie in early modern Bologna. In: V. Zamagni (Ed.), Povertà e innovazioni istituzionali in Italia: Dal Medioevo ad oggi. Bologna: Il Mulino, pp. 131-151.

Spear, R., Cornforth, C. \& Aiken, M. (2009). The Governance Challenges of Social Enterprises: Evidence from a UK Empirical Study, Annals of Public and Cooperative Economics, 80(2): 247-273. DOI: https://doi.org/10.1111/ j.1467-8292.2009.00386.x

Sven, E.O. (2014). Social Policy, Welfare State and Civil Society in Sweden. Lund: Arkiv Academic Press.

Venturi, P. \& Zandonai, F. (2012). Rapporto Iris Network: Limpresa sociale in Italia: Pluralità dei modelli e contributo alla ripresa. Milano: Altra Economia.

Venturi, P. \& Zandonai, F. (2014). Rapporto Iris Network: Limpresa sociale in Italia. Identità e sviluppo in un quadro di riforma. Trento: Iris Network.

Vidal, I. (2001). Spain: Social enterprises as a response to employment policy failure. In: C. Borzaga \& J. Defourny (Eds.), The Emergence of Social Enterprise. London: Routledge, pp. 203-219.

Weisbrod, B. (1975). Toward a Theory of the Voluntary Nonprofit Sector in a Three-sector Economy. In: E.S. Phelps (Ed.), Altruism, Morality, and Economic Theory. New York: Rusell Sdage Foundation.

Weisbrod, B. (1977). The Voluntary Nonprofit Sector. Lexington Mass.: Lexington Books.

Wilson, T. \& Wilson, D. (1993). Beveridge and the Reform of Social Security - Then and Now, Government and Opposition, 28(3): 353-371. DOI: https://doi.org/10.1111/j.1477-7053.1993.tb01321.x

Woolf, S. (1986). The Poor in Western Europe in the Eighteenth and Nineteenth Centuries. London: Methuen.

Woolf, S. (2000). The «transformation» of charity in Italy, $18^{\text {th }}-19^{\text {th }}$ centuries. In: V. Zamagni, (Ed.), Povertà e innovazioni istituzionali in Italia: Dal Medioevo ad oggi. Bologna: Il Mulino, pp. 421-439. 
Young, R.D. (1980), If not For Profit, for what? Lexington Mass.: Lexington Books.

Zamagni, V. (1993). The Economic History of Italy 1860-1990: Recovery after Decline. Oxford: Clarendon Press.

Zamagni, V. (1997). Funzioni e strumenti del Welfare State in prospettiva storica. In: D. da Empoli \& G. Muraro (Eds.), Verso un nuovo Stato sociale: Tendenze e criteri. Milano: Franco Angeli, pp. 3-13.

Zamagni, V. (2000). Introduzione. In: V. Zamagni (Ed.), Povertà e innovazioni istituzionali in Italia: Dal Medioevo ad oggi. Bologna: Il Mulino, pp. 9-13.

Zamagni, V. (2012). A World of Variations: Sectors and Forms. In: P. Battilani \& G.H. Schröter (Eds.), The Cooperative Business Movement, 1950 to the Present. Cambridge: Cambridge University Press, pp. 23-82.

Zamagni, V. \& Battilani, P. (2010). Cooperatives (1951-2001). In: A. Colli \& M. Vasta (Eds.), Forms of Enterprise in $20^{\text {th }}$ Century Italy. Boundaries, Structures and Strategies. Cheltenham: Elgar, pp. 273-293.

Zamagni, S. \& Zamagni, V. (2010). Co-operative Enterprise: Facing the Challenge of Globalization. Cheltenham: Elgar. DOI: https://doi.org/10.4337/9781849805667 